\title{
Immature Myeloid Cells Increased in Bone Marrow
}

National Cancer Institute

\section{Source}

National Cancer Institute. Immature Myeloid Cells Increased in Bone Marrow. NCI

Thesaurus. Code C42776.

An increased number of myeloid precursors in the bone marrow. 